\title{
市政给排水施工中的长距离顶管施工技术分析
}

张博源

天津市赛英工程技术咨询有限公司

DOI:10.18686/bd.v1i12.1140

[摘 要] 在城市中,完善的给排水系统是人们舒适生活和工作的基础设施。市政给排水的工程与施工显得非常的重要,有 着不可或缺的地位。在给排水施工技术中,顶管施工是给排水管道施工技术中的关键敷设技术,在市政给排水工程和企业施 工中应用非常广泛。

[关键词] 市政给排水施工; 顶管施工; 技术分析

\section{1 给排水施工中长距离顶管施工的应用背景}

由于给排水对人们生产生活的重要性。目前, 我们国家 的各个城市都在给排水工程的方面投人了大量的人力、物 力和资金, 以保证市政给排水工程能够更好的为城市的发 展所服务。为了保证给排水工程的效果和工程的质量, 施工 人员不仅要按照国家有关的标准进行严格的施工作业, 还 需要每一个参与施工的人员都对现场的工作情况有所把 控。在具体的施工中,一定要因地制宜的完成市政给排水建 设的任务。给排水工程的设计和组织者也要根据工程的现 场实际情况设计和制定更有效更适合的施工方案。

但是,在实际的市政给排水的规划、设计和施工过程中, 仍然存在着许多的问题。比如给排水网络覆盖面不广导致 的给排水体系和网络不够完善, 一些给排水设施的利用率 低,一些基础设施的管理、维修和养护不够完善等问题。这 些问题的产生, 既有前期规划和设计中的考虑不足所造成 的原因,也有施工技术和施工管理所导致的后果。

\section{2 长距离顶管施工的优点与技术介绍}

2.1 长距离顶管施工技术介绍

顶管施工技术是一种非开挖的施工方法，在施工中不 开挖或者少开挖来完成管道施工的技术。长距离顶管施工 利用顶管管内的油压压力和顶管受到的土体压力的联合作 用,克服管道与周边土壤的摩擦, 来实现设备在土体内的推 进。在顶推压力的共同作用下,使用类似盾构的技术,用刀盘 旋转进行土体的切削。为提升切削下来的土体的外运效率, 采用蜜蜂土仓进行切削土体的压缩, 然后由螺旋输送结构 对土体进行不间断的运输。在这个过程中, 为保证压缩后土 体的运输顺利, 还需要施工人员根据具体的土体和土质情 况,进行合理的配比, 向土仓内加人一些辅助性材料, 比如添 加剂或者泥浆等材料, 将一些难以运输的土体进行结合和 改造,形成适合工程所需要的土体。保证顶管长距离施工的 连续化推进。

2.2 长距离施工中顶管施工技术的优点

我国城市化进程发展迅速, 各种建筑构成的城市整体 日趋完善。但是局部新建城区和部分老城区的给排水系统 建设还是出于比滞后和较落后的状态。对污水的排放能力
也无法满足现代化生活的需要, 也无法满足我国城市对环 保的基础要求。对这些地区进行市政给排水的基础设施建 设就成了一项很重要的任务。但是, 在已有的城市环境下, 如 果采取传统的市政给排水施工方式进行建设和改造, 就要 进行大规模的开挖工程。有着很多的缺点:

首先, 按照传统方式进行地面的挖掘还填埋浪费和消 耗了大量的人力物力以及资金。

其次,传统方法施工进度缓慢,而且对市容市貌和人们 生产生活影响很大。特别是在一些人流和交通密集的地区, 传统的先开挖再填埋的方法会极大的影响到城市的交通秩 序和居民的正常生活

最后, 影响城市的管理工作。由于大规模的露天挖掘, 以 及前两点的影响,对城市的管理也带来的不小的麻烦。需要 投人更多的精力以及人力物力来配合工程的施工, 还要保 障施工阶段人们出行的交通疏导等等工作。对城市日常的 管理工作产生了不小的影响。而长距离顶管施工为解决这 些难题提供了一个有效而且可行的解决方案。

首先, 由于长距离顶管施工无需大量的进行工程的开 挖, 大量的减少了工程的土方作业量, 在人力物力和资金上 有着显著的减少。

其次, 该方法由于减少了地面的工程量, 对地面的交通 和生活影响程度大大的减少。

第三,方便进行不间断的施工作业,提升了工程的效率 和节省了工程所耗费的时间。

第四,顶管施工非开挖的施工方式提升了施工安全性。

总之顶管施工技术的应用, 可以给市政给排水的建设 提供更好的施工选择, 其适应能力与优点能够满足未来不 断发展和增长的给排水建设的需要。

3 长距离顶管技术在市政给排水施工中的具体应用说 明

某市区市政道路进行规划和施工，道路工程按照双向 六车道进行规划施工, 宽度为 18 米, 长约 500 米。道路需要 对雨水管网进行安装, 雨水管网安装完成后与下游道路排 水管道进行连接,纳人城市的整体排水体系。为提高排水施 工效率和施工质量以及节省施工成本。经过全面勘察设计, 
决定根据实际情况采用非开的施工技术，具体的就是采用 顶管施工技术和水平螺旋钻进施工技术共同完成施工目 标。并加大对通风系统的建设,为施工人员提供保护,保证施 工中的安全环境。

3.1 非开挖顶管施工技术的应用范围

在城市市政建设当中, 为了提升给排水施工的效率和 质量, 对长距离顶管施工技术进行了大量的创新。非开挖顶 管施工技术就是在这些技术中脱颖而出并广泛采用的。目 前,在使用这项技术的工程中,都呈现出了不错的经济性和 很好的施工效率和施工质量。尽管非开挖顶管施工技术有 着非常多的优点和优势, 很多的施工企业和市政单位也对 其有着高度的关注。但是非开挖顶管施工技术的相关理论 和研究还不多, 相关的技术和管理人员应该加大研究的关 注度,对其施工的重点和要点加以深人的研究。

现阶段, 我国的给排水的传统施工技术已经逐渐被非 开挖顶管施工技术所取代。越来越多的工程在不影响到人 们生产生活的同时就能够很好的完成。但是,非开挖顶管施 工技术进行施工的过程中,也有一定的限制性,如果没有很 好的处理其中的问题和要点, 就会导致严重的偏差和问题, 导致工程的失败。因此,要在选择施工方式的时候,从市政具 体的情况出发,合理的采用非开挖顶管施工技术,充分的发 挥这个技术的优越性和价值。

由于非开挖顶管施工技术是一项比较新的技术, 在采 用非开挖顶管施工技术的时候, 要对施工人员进行技术上 的专门学习和指导, 施工人员必须要掌握顶管技术在施工 中的原理和过程。只有这样,才能在保证安全的前提下,提升 市政给排水施工的效率,并且保质保量的完成施工的目标。

在采用非开挖顶管施工技术的时候, 还要注意的是管 道的设计要对非开挖顶管施工技术进行优化。合理的设计 才能够很好的利用非开挖顶管施工技术, 从而提升管线工 程的质量。而且在发生问题的时候, 要及时的予以重视和解 决, 保证非开挖顶管施工技术能够为市政给排水工程的综 合效益起到良好的作用。

3.2 顶管施工技术

顶管施工技术就是非开挖施工的方法。在市政的给排 水工程中,如果进行顶进钢套管施工,通常都会应用顶管施 工技术。既可以不影响到其他公共管线的正常使用,也可以 更迅速的完成施工任务。

具体的施工工程要点如下:
首先需要在地标设置或者挖掘两个基坑井, 并在基坑 井内水平放置钢管, 并使用千斤顶类的机械向设计好的方 向进行顶进。

其次,对出口进行预留,只有这样才能保证和验证顶人 的出发井与接收井以及土层之间的紧密联系, 在此基础上 完成的管道施工和管道质量更加符合标准的要求。

3.3 水平螺旋钻进施工技术

水平螺旋钻进技术也是市政给排水管道施工中常用的 技术之一。该技术是指钢管在向预留的目标井顶进的时候, 要对水平螺旋钻杆进行充分的应用。目前,我国对该技术在 给排水施工中的应用已经构建了比较健全的管理规章和相 关的制度。以确保实际工程中该技术安全合理的使用。需要 注意到的是,这个技术的应用范围一定要适合目标工程。只 有在小恐惊钢筋混凝土排水管道的施工中才可以进行充分 的使用。

螺旋钻进技术的控制难点在于操作人员对钻进方向有 较大的控制难度,在实际工程中很容易产生一定的偏差。这 就需要施工人员努力加大控制水平和控制力度, 在技术方 面加以创新,才能更好的实现工程的目标,为市政排水工程 打下良好的基础。

3.4 通风系统

长距离顶管技术由于施工位置的原因, 保证通风是安 全施工的关键措施之一。而且由于施工的距离比较长, 工作 人员的氧气不足成为安全生产的最大危险。所以必须要设 立和保证安全可靠的通风系统, 为施工人员提供安全的施 工环境。通风系统还可以使得施工时候使用的涂料等挥发 的有害气体及时的排出,降低有害气体的威胁。

\section{4 结语}

长距离顶管施工技术的有效应用, 有效的解决了给排 水施工中由于开挖面积大、对人们生活影响大的问题, 不仅 可以提升工程的效率和保障工程的质量, 还可以为人们的 生活提供更多的方便,为城市的健康发展做出贡献。

\section{参考文献:}

[1]王灿.浅谈市政给排水施工中的长距离顶管施工技 术[J].民营科技,2015,(10):138-138.

[2]黄覀.市政给排水长距离顶管施工影响要素及控制 要点分析 [J].江西建材,2015,(18):74-75.

[3]刘悦明.市政给排水施工中长距离顶管施工技术研 究[J].四川水泥,2018,(02):136. 